\title{
Philosophiques
}

\section{Stanley Rosen, The Question of Being. A Reversal of Heidegger, New Haven and London, Yale University Press, 1993, 344 p.}

\section{Jean-Marc Narbonne}

Volume 23, numéro 1, printemps 1996

Critères esthétiques et métamorphoses du beau

URI : https://id.erudit.org/iderudit/027377ar

DOI : https://doi.org/10.7202/027377ar

Aller au sommaire du numéro

Éditeur(s)

Société de philosophie du Québec

ISSN

0316-2923 (imprimé)

1492-1391 (numérique)

Découvrir la revue

Citer cet article

Narbonne, J.-M. (1996). Stanley Rosen, The Question of Being. A Reversal of Heidegger, New Haven and London, Yale University Press, 1993, 344 p.

Philosophiques, 23(1), 163-171. https://doi.org/10.7202/027377ar d'utilisation que vous pouvez consulter en ligne.

https://apropos.erudit.org/fr/usagers/politique-dutilisation/ 


\title{
ÉTUDES CRITIQUES
}

\author{
Stanley Rosen, The Question of Being. A Reversal of Heidegger, New \\ Haven and London, Yale University Press, 1993, 344 p.
}

PAR

JEAN-MARC NARBONNE

"Heidegger ou la gageure impossible ", tel aurait pu ètre le titre de l'ouvrage de Rosen, tant celui-ci insiste tout au long de son essai sur l'impossibilité, voire l'ineptie, du projet heideggérien de questionnement sur l'ètre.

Pensons un instant à l'idée de "nature ", phusis, qui introduit mieux que toute autre peut-être à la représentation que se fait Heidegger de l'Être pris au sens large, c'est-à-dire par opposition ou abstraction faite des êtres particuliers. des étants singuliers (ta onta). L'effort de Heidegger est alors comparable à celui de qui chercherait à savoir ce qu'est la nature en tant que telle, non pas la nature de tel ou tel ètre naturel pris singulièrement, mais la nature, pour ainsi dire. de la nature elle-mème, en se refusant le détour par les êtres naturels, les différents visages derrière lesquels la nature se dissimule et à travers lesquels tout à la fois elle se manifeste sans se montrer véritablement. En découvrant un visage, à chaque fois un aspect seulement d'elle-mème, la nature dissimule son propre visage, ou mieux encore, nous fait oublier son fond sans visage, toujours autre que le visage qu'elle affiche et pour laquelle nous la prenons. En considerant ses multiples visages, c'est elle qui git derrière que nous oublions, que nous occultons et que nous réifions. Ainsi en est-il de l'Être, que nous oublions au profit des étants, distrait que nous sommes de la véritable question de l'Etre par les étants, par ce qui se montre et prend visage, ce qui se présente, comme si l'Être résidait ou se limitait à cette présence. C'est ainsi que nous ramenons l'essence de l'être à la présence, l'ousia à la parousia, et que nous restons sourds à la voix de l'Être proprement dite. La vérité de la nature ou de l'Etre n'est pas ce qui apparait, mais ce qui disparait dans cet apparaitre mème.

On sait que le terme phusis est éminemment polysémique dans la langue grecque. Aristote, par exemple, entend par nature tout à la fois la forme d'un ètre prise isolément, mais aussi sa matière. ce de quoi il est fait, de mème que la chose concrète, c'est-à-dire le composé en acte (suntheton), qui est dit non pas nature au sens strict mais exister par nature (phusei). Est nature aussi ce qui existe réellement, ce qui constitue une réalité objective, comme lorsque Aristote déclare que le principe et la cause sont une seule et mème nature (mia phusis. Mét. 1003 b 23-24). La nature, enfin, est prise en compte dans un certain nombre d'énoncés généraux, comme lorsque Aristote déclare que " la nature ne fait rien d'irrationnel ni de vain " (Cælo, 291 b 13), qu'elle "réalise toujours la meilleure des possibilités " (Cælo, 288 a 2-3), ou encore que, "comme le bon économe, elle n'a pas l'habitude de jeter ce dont elle peut tirer usage "(Gen an, 744 b 16). Dans tous ces cas, la nature est prise ou bien comme ce qui se présente de telle ou telle manière ou accomplit tel ou tel rôle, ou bien comme un 
principe ordonnateur abstrait dont la récurrence des phénomènes nous fait intuitionner l'économie particulière. La compréhension de la nature passe ainsi par l'examen des différents états que celle-ci connait, soit qu'on les considère en eux-mèmes, soit qu'on tire de leur présentation d'ensemble un enseignement sur la nature prise dans sa globalité. Quand Aristote réfléchit au fait qu'il est ridicule de vouloir démontrer que la nature existe - puisqu'elle est ce qu'il y a de plus manifeste et qu'il faudrait alors démontrer ce qui est plus manifeste par ce qui l'est moins - il prend appui non pas sur le fait qu'il y a une nature pris au sens abstrait, mais qu'il est manifeste (phaneron) qu'il existe plusieurs ètres qui sont tels, c'est-à-dire plusieurs ètres naturels.

On ne peut parler de la nature sans passer par les entités naturelles, ce qui est évident, mais aussi, ce qui est plus important, sans admettre que ces entités sont une voie légitime d'accès à la nature. Ils sont du reste la seule. On ne peut pas davantage interroger directement la nature en tant que nature que, comme Aristote l'a montré, l'être en tant qu'être. Ce sont les entités naturelles qui nous donnent une idée, par définition imparfaite et toujours à corriger, de la nature, et pas l'inverse. On ne peut rien tirer, si tant est que la chose soit possible, de la contemplation du sans-visage en tant que sans-visage, qu'il s'agisse de la nature ou de l'Étre, et appeler nihilisme le fait. qui est celui de toute la tradition philosophique, d'aborder la nature ou l'Étre par ce qui se donne à voir et à penser, par ce qui prend figure et détermination et qui encore une fois, est notre seule voie d'accès possible à l'étre - une nécessité, pour ainsi dire, de l'Être lui-mème, qui n'autorise aucun autre mode de monstration tient de la mystification pure et simple.

Il en résulte deux attitudes philosophiques possibles : l'une, développant une stratégie du soupçon et de la méfiance, nous inviterait à nous détourner des étants trompeurs dont nous n'apercevons que l'aspect outil (Vorhandenheit / Zuhandenheit) - d'où la mauvaise technique, le mauvais logos réducteur - en faveur d'une attention au sans-objet, d'une écoute du sans-voix, l'être en tant qu'être, ineffable, sans contenu, mais vrai; l'autre, nous incitant à nous préoccuper, comme du reste de la seule tâche réalisable, des étants, à les comprendre et à les adapter en vue d'une vie bonne, plus facile et pratique. sans se méprendre sur la vision nécessairement perspectiviste qui est la nôtre de cette totalité de l'être dont nous faisons partie.

C'est en ces termes que Rosen conçoit l'opposition du platonisme et de l'heideggérianisme. En voici quelques exemples:

the renewal of Platonism is equivalent to the renewal of philosophy, not because Platonism is identical with all philosophical hypotheses, but because it is the attempt to account for the whole [par le biais de ses parties]. Heidegger's attempt to distinguish the thinking of the whole from the thinking of the origin is then not philosophy but theology : or rather, it is the atternpt to replace logos with a new kind of thinking that conforms to the nonontic nature of the origin. Everything comes down to the question of whether such thinking is possible and, if possible, whether it is desirable. For the Platonist, this much is certain We cannot begin with a pursuit of the origin. Such a pursuit deprives us of our bearings; it empties life of significance rather than enriching or illuminating it (p. 179)

Whether he speaks for Nietzsche or for himself. Heidegger has nothing to say of any value for our attempt to live a good life, other than to issue the injunction to listen to the voice of Being, which wnfortunately does not seem to be saying anything in particular (p. 217)

I understand very well that what Heidegger actually advises is a shift in attitude toward beings. But in allowing things to be, we are adopting a superflwous posture, one that simply masks our continuing need to make use of that which presents itself. Even worse. we cover with obscurantism the pressing need to modify their " presents, some of which 
are acceptable in their present form and many of which are not. In the not-so-long nur. submission to the celebration of the eventing of the E-vent is more dangerous than the natural inclination to master and possess nature (p. 263)

So far as ow main theme is concerned, it is utter nonsense to accuse Plato of nihilism on the grounds that he neglects Being in fawor of beings. The neglect of beings is in itself disastrous. But the attempt to derive the " genuine * or - original " response to beings from an immersion in a Being that has no value and no purposiveness, but simply happens, is absurd (p. 265)

Beings are useful in general because without them nothing can be accomplished, including the search for the sense of Being. (...l it is for reasons like these that I an not much impressed by his [Heidegger/ reiterated thesis that metaphysics is nihilism If the charge of nihilism is to be leveled at all then it must be leveled against the presencers and eventers. since they seem to value nothing at all or, what comes to the same thing. since they replace the Idea of the Good with the facelessness of the event. (p. 268-269)

Comme on peut s'en rendre compte, Rosen s'en prend à toute l'entreprise heideggérienne, jugée absurde à la fois en elle-mème et dans ses aboutissements (on verra plus loin qu'elle l'est aussi dans son détail, notamment dans sa lecture de Platon et de Nietzsche). La question de fond, de lignée aristotélicienne, est en définitive le découpage erroné de l'être auquel la pensée heideggérienne parvient et qui culmine dans ce que Rosen appelle la théorie du "surplus de l'être " "Surplus Theory of Being "). La difficulté, insiste Rosen (p. 192), réside dans le fait de vouloir penser l'Être par delà l'errance de l'Être, c'est-à-dire par delả les différents dons (étants) de l'Être-processuel. Dans ce cadre, explique-t-il. trois éléments ou dimensions ontologiques sont à considérer. Il y a d'abord l) les étants particuliers, craie, tableau noir, arbre, pierre, etc. ; il y a ensuite 2) l'ètre commun à toutes ces choses manifesté par le verbe "est "dans des phrases du type " ceci est une craie ". "ceci est un arbre ", etc. : il y a enfin 3) l'Être qui nous met en présence des choses et des attributs communs aux choses ou des catégories par lesquelles nous définissons ces choses. Dans ce troisième sens, l'Ētre est un simple processus par lequel les choses peuvent étre manifestées, et il n'est dès lors, remarque Rosen (p. 192) ni une chose ni méme l'être d'une chose, en parallèle, peut-on ajouter, avec la formule aristotélicienne des Seconds Analytiques selon laquelle "l'être ne sert d'essence à aucune chose " (92 b 13). C'est évidemment ce troisième sens "supplémentaire " de l'être qui pose problème. Le premier sens de l'être constitue l'objet des arts et des techniques. Le second est celui de la métaphysique et de son rejeton, la logique. Mais le troisième ? Si le deuxième sens est suffisamment large pour inclure non seulement l'essence des choses, mais aussi les événements, puissances, vertus, relations, et tout ce qui est identifiable comme un être d'une certaine sorte, qu'est-il besoin d'un troisième sens? Qu'est-il besoin, pour reposer le problème en terme de phusis, d'un troisième concept de nature audelà de celui que recouvre les étants naturels et les lois, phénomènes, événements, puisances naturels que l'on peut induire à partir de ceux-là ? Si les deux premiers sens recouvrent déjà tout ce qui peut ètre dit de l'ètre, puisqu'ils renvoient non seulement aux étants mais à l'ètre en tant qu'ètre lui-mème. par la considération des différentes catégories et modalités par lesquelles l'être. essentiellement multiple. se déploie et se manifeste à nous, qu'advient-il du troisième sens, dont on ne peut parler sans le réifier, c'est-à-dire sans le déplacer et le travestir, comme l'ineffable de la tradition de la théologie négative qui reste toujours au-delà de ce qu'on peut en dire et dont on doit nier tout ce qu'on en affirme? Il s'ensuit alors, comme l'écrit Rosen : 
that all that I can say about openness [l'Être comme pur processus d'ouverture visé par Heldegger] is that it conceals itself in the granting of uncoveredness. But this means thrt I cannot say arything positive or affimative, that is, determinative, about openness. To do so would be to reify it, that is, to make real predications about it. Being qua openness is a surplus of beings qua uncovered, and so of the being of beings qua uncoveredness. But it is a vacuous or invisible surplus. Fundamental ontology, or its subsequent replacement. the recollective or rememorative meditating about Being, tums out to be very much like a poetic supplement to negative theology, not to say silence. The joumey from the distinction between real and logical predicates to the ontological difference and beyond is finally revealed as a progressive dimirution of the sense of Being. In the case of the surplus theory of Being, more is less. (p. 210-211)

Ce n'est pas le fait de se porter vers l'inconnu, c'est-à-dire vers le nondécouvert qua non-découvert que Rosen reproche à Heidegger - qui pourrait reprocher une telle chose? - mais le fait de prétendre éclairer le connu par l'inconnu et l'inconnaissable au détriment du connu interprété comme une occultation de l'inconnu. En termes platoniciens, l'on dirait que les copies sensibles ne peuvent mème plus servir d'amorces à la réminiscence, que la contemplation des Idées et du Bien doit se faire en marge des copies dont elles sont pourtant les modèles. C'est cette démarche, dont Rosen soutient à juste titre qu'elle nous prive de nos points de repère et vide la vie humaine de toute signification $^{1}$, qui fait de Heidegger un mauvais poète ${ }^{2}$. Encore une fois, critiquer la théorie du surplus de l'être ne revient pas à dire que l'Être n'est pas, mais qu'on ne peut en parler ou se mettre à son écoute comme nous $y$ incite Heidegger : " My point is not that there is no Being; this is an unintelligible claim. My point is that we cannot talk coherently about Being. Even the injunction against such talk is incoherent. The difficulty with Heidegger's language is not that it is theoretically complex or technically sophisticated; the difficulty lies in the fact that he is not talking about anything at all as he himself insists " (p. 119).

Vider la vie de son sens, c'est ce qui résulte de l'invitation inconditionnée à tendre, toutes affaires cessantes, l'oreille à la voix sans voix de l'Étre, mais aussi du rapport que Heidegger tend à établir entre le Dasein lui-mème et l'Étre. Nous pensons ici à la thèse de l'oubli de l'être dont on peut se demander s'il est constitutif de l'homme - et en ce sens nécessaire et déterminé - ou s'il est la conséquence d'une errance prolongée (c'est-à-dire de Platon au moins (!) jusqu'à Heidegger), mais néanmoins provisoire de la pensée humaine - et en ce sens contingent. En d'autres termes, l'occultation réifiante platonicienne et par conséquent métaphysicienne (puisque toute la métaphysique, insiste Heidegger, est du platonisme) est-elle une nécessité de l'Être lui-même, la conséquence inévitable du mode de monstration propre à l'Être, ou le résultat d'une mécompréhension ou d'une occultation inhérente à la pensée platonicienne, et en général, métaphysicienne, jusqu’à Heidegger ?

Sur cette question fondamentale, écrit Rosen, la pensée de Heidegger reste imprécise : "it is never clear whether Plato's "fall" was necessitated by the veiling-over of Being through beings, or whether this fall might not have been averted through adhence to the doctrine of the pre-Socratic thinkers. Was the history of metaphysics necessary or contingent?"(p. 182). Dans les textes (mais pas seulement) ou le thème de la Gelassenheit est présent, c'est l'idée de l' errance " nécessaire qui parait privilégiée, alors que d'autres textes font allusion à

1. * Such a pursuit [de l'origine] deprives us of our bearings; it empties life of significane $\gg$ p. 179.

2. "My objection to Heidegger is not that he engages in poetry, but that he is a bad poet $\gg$ p. 43. 
un " nouveau commencement dont la possibilité dépendrait d'une nouvelle écoute de l'Être et de sa vérité. Or, outre le fait qu'on ne voit pas très bien ce que l'Être en soi non réifié d'aucune manière pourrait avoir de particulier à révéler, c'est l'évocation mème de la possibilité d'un autre commencement qui invalide la thèse heideggérienne maitresse du don-occultation inhérent au mode de monstration propre de l'Être :

either Being works its way on mortals, or else the history of Western philosophy is made up of a contingent series of interpretations $(. .$.$) In the former case. Heidegger is a mere$ mouthpiece for the current indeterminate period, a kind of entr'acte between what may be two acts of the world-epoch of metaphysics or a genuine pause before the initiation of the other begivining. In the latter case, his accourt of Being as a process of gift-giving is radically defective and perhaps untenable. By attributing the history of Being to an origin of which we are the consequence. Heidegger in effect identifies the errance of thinking with the errance of Being. As we shall see soon, this is aiso the doctrine he attributes to Nietzsche... (p. 183-184)

Le choix, pour l'heideggérien, parait en effet bien mince entre le fait de subir la loi de l'Etre ("With respect to the E-vent, nothing happens; the E-vent eventuates ", p. xvi) et de se mettre à l'écoute de la voix sans message de l'Être (" Heidegger is right to say that Being presents itself in a concealed form. He is wrong to try to persuade us to think Being apart from its modes of concealement " $\mathrm{p}$. xxixxii ; " nothing or next to nothing can be said about Being. And this is why I contend that metaphysics is rooted in silence * p. 43).

La pensée de Heidegger est insatisfaisante dans son ensemble, c'est-à-dire dans ses propositions générales. Mais elle l'est aussi dans son détail, notamment dans sa lecture de Platon et de Nietzsche.

De la lecture heideggérienne de Nietzsche, longuement analysée dans la seconde partie de louvrage intitulée " Reversed Platonism ", Rosen retient surtout l'importance démesurée accordée à la doctrine du Chaos. Selon Heidegger, "Nietzsche's metaphysical teaching is contained in the twin doctrines of the will to power and the eternal retum But these doctrines themselves reduce to the thesis that Being is intrinsically Chaos. What returns etemally is the finite number of comprehensive permutations of Chaos. Nietzsche is then if a metaphysician at all, a metaphysician of Chaos" (p. 153). Le Chaos est l'éternel retour, animé non pas par une loi mais par une nécessité irrationnelle. dont la volonté de pouvoir peut elle-mème etre interpretee comme une manifestation: "from the standpoint of the Nietzschean philosopher, the projection by man of a horizon is itself an illusion; the true explanation of this illusion is that it is an epiphenomenon of the random disturbances of Chaos " (p. 161). Il n'est pas bien difficile, comme le remarque Rosen, d'établir le lien entre le Chaos nietzschéen et l'Être heideggérien lui-même: "Chaos is the ancestor of Heidegger's understanding of Being as a process of emergence. To attribute a structure to Chaos is equivalent to attributing a structure to Heideggerian Being and thereby to rationalizing or reifying it " (p. 162). Or ce que Rosen conteste en cette affaire c'est non pas l'existence proprement dite de ce courant moniste nietzschéen tendant à tout interpréter comme un effet du chaos, mais que ce courant soit le seul présent et actif chez Nietzsche : "Nietzsche never follows the implication of his own doctrine of Chaos, namely, to obliterate human existence by transforming it into "irrational necessity" "(p. 217). Selon Rosen, Nietzsche reste un penseur dualiste - à la volonté de pouvoir s'oppose en effet chez Nietzsche la doctrine de l'êtemel retour. et si l'on trouve d'un côté chez lui une interprétation cosmologique de la volonté de pouvoir, on trouve aussi de l'autre, en contrepartie, une interpretation humaine de l'éternel retour (cf. p. 225) - en dépit des efforts de Heidegger pour 
découvrir en lui une doctrine unitaire, et si le Nietzsche de Heidegger peut se comprendre comme une tentative de remplacer le dualisme par le monisme (cf. p. 230), c'est qu'à toutes fins pratiques, "there is no difference between Heidegger's Nietzsche and Heidegger himself " (p. 222).

S'agissant de la lecture heideggérienne de Platon. la critique de Rosen est aussi ample et radicale que la précédente.

Réduite à sa plus simple expression, l'interprétation heideggérienne de Platon énonce ceci : "Plato initiates the shift in attention from awamess of Being as the play of presence and absence to a conception of Being as pure or genuine presence, namely, as the presence of the bok, that by which we identify what a thing is : the idea "(p. xv). Pour Platon, selon Heidegger, l'être se ramène ainsi à l'Idée. Or, toujours selon Heidegger (tel qu'analysé par Rosen), ce privilège accordé à l'Idée a pour conséquences 1) de favoriser l'oubli du voilement de l'Être par les étants ; 2) d'introduire une sorte d'utilitarisme ou d'instrumentalisme ontologique ; 3) de remplacer l'interprétation originale grecque de l'Étre comme phusis par une conception productiviste de l'Étre telle qu'elle est exemplifiée par la fabrication artisanale : 4) le développement ultérieur chez Aristote de la doctrine des catégories et de celle de l'étre en tant qu'ètre. A quoi Rosen répond que 1) l'Être est en effet cachè par les étants, raison pour laquelle on doit toujours s'orienter à l'aide de ceux-ci et non pas tenter de s'orienter à l'aide de celui-là ; 2) l'accès aux étants est en soi pour l'homme une bonne chose ; 3) la doctrine de l'Être chez Platon n'est pas productiviste, même si l'on trouve chez lui une doctrine de la vie comme pratico-productive : 4) les Idées platoniciennes sont les prototypes des espèces-formes aristotêliciennes, mais non des catégories et de l'être en tant qu'être ( $c f$. p. 44).

Nous avons déjà suffisamment parlé des points 1 et 2 pour ne pas y revenir maintenant. Le point 3 est plus important puisqu'il rejoint la compréhension même de l'Idée dans le corpus platonicien. Selon Heidegger. Platon renverse l'ordre normal entre eidos et morphê dans la perception sensible. Au lieu que l'eidos soit obtenu par la morphê telle qu'elle est reçue dans la sensation, c'est. dans le platonisme, l'eidos invariable entendu comme antérieur et indépendant des étres particuliers qui sert de fondement et rend compte des formes particulières sensibles (cf. p. 6). En ce sens, l'eidos peut ètre interprété comme un " produit ", le résultat de l'activité de l'intellect humain (prototype de l'intellect divin) et Platon, le premier philosophe à défendre une conception productiviste de l'ètre dans laquelle l'être est compris au sens premier comme une "production *. L'on comprend à partir de là que Platon soit le véritable initiateur de l'idéalisme subjectiviste moderne qui réduit l'ètre à l'être-pensé : "Heidegger is thereby able to treat the doctrine of the Ideas as the prototype for the productive ego cogitans (...). Modemity presumably arises from the mistaken interpretation of technè as manifacture, and so of natural production as technical in this sense. Otherwise expressed, it arises from the shift, initiated by Plato, from uncoveredness as a property of beings to uncovering as an activity of the thinker-maker * (p. 11).

L'erreur d'appréciation consiste ici, comme l'explique Rosen, à mal mesurer non seulement le rōle de l'intellect humain, mais celui de l'intellect divin, dans la saisie des Idées. Au livre $\mathrm{X}$ de la République notamment, l'activité artisanale de dieu vis-à-vis de l'Idée est celle d'un jardinier (phutourgos $597 \mathrm{~d}$ 5) et non d'un producteur. En un mot, "The demiourgos, or craftsman, is one who makes implements like beds and tables for the dèmos, or people, that is, for everyday life. But even he must make his implements "by looking to the Idea ". And neither he nor any other craftsman can make the Idea itself, which is "preordinated" and to which he is "subordinated" "(p. 14). Bref, la métaphysique productiviste 
diagnostiquée chez Platon par Heidegger est, sinon fausse, au mieux une simplification outrancière de la pensée platonicienne.

Du quatrième point, on retiendra enfin que le schème eidétique platonicien est differrent du schème catégorial aristotélicien : " the universality of the concept of Being relative to the categories is not the same as the "community " of the Idea with respect to its instance (...). The "look" of the cow has in common with all natural cows not the being but the way of being (...). On the other hand, the universal "Being " has in common with all categories not a look, but the property of being itself,$(p .22)$. Le plus loin que Platon soit alle dans le sens des catégories aristotéliciennes, dans le Sophiste, le Philèbe ou le Parménide où il est question de l'ètre, du mème et de l'autre, du mouvement et du repos, ou encore de la limite et de l'illimité. sont des textes en eux-mèmes non concluants qui ne permettent pas de dégager " an average concept of Being " (p. 24) platonicien.

Nous avons résumé dans les pages qui précèdent les thèses principales de l'auteur en laissant transparaître au passage, on s'en sera aperçu, notre accord global avec l'orientation générale de l'ouvrage. En plusieurs points, Rosen fait preuve de finesse et, disons-le, de bon sens dans ses analyses des positions heideggériennes. Sur deux points cependant, liés dans une certaine mesure l'un à l'autre, l'exposé de Rosen nous a paru insatisfaisant. L'un est l'interprétation de la nature et du rôle des Idées chez Platon, l'autre est le jugement porté sur la pensée d'Aristote, que ce soit dans son rapport à Platon ou à Heidegger.

Commençons par la doctrine des Idées à laquelle Rosen consacre de nombreuses pages dans la première partie de l'ouvrage. La première question qui vient à l'esprit est de savoir pourquoi l'auteur prend tant de soin à expliquer et à justifier la valeur d'une doctrine dont il soutient par ailleurs qu'elle n'existe pas, qu'elle est une invention du XIX siècle : "As to the theory of Ideas, it is an invention of nineteenth-century historical scholarships, based not upon the Platonic dialogues but upon Aristotle "(p. 29). Gue tout le platonisme ne se réduise pas à l'Idée - Rosen rappelle à ce propos l'importance de la doctrine de l'Eros et la dépendance du logos à l'égard du muthos chez Platon -, bien peu en disconviendront. Que les différentes présentations de la doctrine des Idées dans les dialogues platoniciens ne conduisent pas à une doctrine bien définie de l'Idée (cf. p. 28) - mais la mêrme chose pourrait ètre soutenue à propos de la thèorie de la substance chez Aristote - , on peut aussi l'admettre sans peine. Un fait demeure cependant, c'est que l'Idee, chez Platon, existe, et que l'insistance même de Rosen à montrer à quelle condition elle " existe ", à quelle condition elle est opératoire, c'est-à-dire à quelle condition elle est une hypothèse plausible et défendable, le rapproche dangereusement des "théoriciens " qu'il incrimine.

S'agissant de l'* existence " elle-même de l'Idée, les propos de Rosen restent ambigus. Réduit à sa plus simple expression, le paradoxe de l'Idée - qui est un paradoxe platonicien et non bien sür rosenien - peut s'énoncer comme suit: pour ètre utile et servir effectivement de paradigme dans la connaissance. l'Idée doit à la fois être différente des copies dont elle assure la connaissance. plus accessible et plus claire (l'Idée de cheval différente des chevaux individuels), sans quoi nous n'aurions pas besoin de recourir à elle, et en mème temps, identique à elles, sans quoi la connaissance du modèle ne nous assurerait pas celle des copies. Toute la difficulté de la séparation est là. L'Idée doit à la fois ètre distincte et identique, ou en d'autres termes, séparée (pour ètre autre chose) et unie (pour être la même chose). Or Rosen affirme catégoriquement que la séparation de l'Idée n'importe comment ne fait pas de sens: "the doctrine of separate Ideas makes no sense whatsoever " (p. 77). Reste donc à savoir si l'Idée peut ètre unie sans être identique, ou si l'on préfère, distincte sans être séparée. 
Or il ne le semble pas si l'on en croit des déclarations du genre : "The Idea is also ontôs on in contrast with the spatio-temporal or generated particular " (p. 78) : "Socrates evidently means to suggest that the Ideas or looks are accessible within, but are themselves different from, the logoi in which they are presented * (p. 81). Gue cette manière différente et contrastée d'exister pour l'Idée implique bel et bien une séparation selon Rosen est ce qui ressort de l'opposition de la doctrine platonicienne et de la théorie selon laquelle les universaux sont obtenus par abstraction :

The Idea is supposed to subsist independently of our thinking $[. .$.$) The abstraction [. .$.$] is$ supposed to exist nowhere but in our thoughts. I have already pointed out that this duplicates the problem of the ostensible separateness of the Ideas from their participants, with the added disadvartage that being is now identified with thirking. In order to overcome this disaduantage, the concept must be distinguished from the ant of conceptualization In this case the concept of the cow is neither the particular loak of some historical cow nor an intellectual artifact but an independent, cognizable being that reveals truth about cows. In other words, it is the Platoric Idea. Such a concept can be neither generated nor destroyed (...) It is for ever itself, apart from its appearances, both in cows and in our thoughts. (p. 92)

C'est cette même difficulté relative au statut de l'Idée qua séparée à laquelle se heurte Rosen sans succès qu'Aristote s'était efforcé - non sans heurts - de résoudre par ses propres moyens en arguant pour l'immanence de la forme dans le sensible. En soutenant que la Forme n'est pas séparée de la chose, Aristote fait en sorte que la connaissance de la forme garantisse celle de la chose. La forme ou l'Idée n'est pas séparée, c'est-à-dire subsistante par soi en dehors des individus, mais elle est plutôt en puissance dans le composé, qui est la vraie substance et qui ne peut, par conséquent, être composée d'éléments qui subsisteraient déjà par soi, comme substances en acte: "Il est impossible qu'une substance provienne de substances qu'elle contiendrait comme en entéléchie, car des êtres qui sont ainsi deux en entéléchie ne sont jamais un seul ètre en entêléchie "(Mêt. 1039 a 3-5). Or c'est pourtant ce qui s'ensuivrait si argument du Troisième Homme - l'Idée existait déjả par soi. Ce serait elle, et non la chose qui en participe, qui serait substance. En un sens, donc, pas très éloigné de celui entrevu par Rosen, la forme, insiste Aristote, ne peut être séparée de cela dont elle est la forme. Mais il n'empèche que. cette fois contre Aristote, la forme dite en puissance dans le composé demeure, mème si elle est en puissance, "séparée "en fait du composé. Ce qui le montre est le fait que la forme aristotélicienne, comme l'Idée platonicienne, est ingénérable et indestructible, éternelle et stable, et que, tout en ètant inhérente au sensible, elle reste indifférente - et donc en ce sens séparée - aux variations propres au monde sensible. En d'autres termes, s'il y a un monde intelligible, éternel, stable et paradigmatique chez Platon, il y a une structure intelligible du monde chez Aristote, elle aussi éternelle, stable et paradigmatique. La forme est donc bien dans le sensible chez Aristote, mais elle y est, paradoxalement, comme si elle n'y était pas. La forme aristotélicienne, qui est aussi, on le voit, platonicienne, atténue sans réussir à l'abolir l'opposition platonicienne du modèle et de la copie.

Rosen eût dù ètre sensible à cette tentative de solution, au fond assimilable à la sienne. Or la doctrine aristotélicienne de la forme se transforme sous sa plume en un "darwinisme " avant la lettre: "If the Platonic Idea of the cow is separate from historicai cows, then the disappearance of cows from history is not going to affect the Idea of the cow. Darwinism poses a problem for Aristotelianism, but not for Platonism " (p. 107). Est-il nécessaire de rappeler que le darwinisme ne représente aucunement une menace pour Aristote, qui tient et répète que la 
genèse est en vue de la forme, plutôt que la forme en vue de la genèse : "La genèse découle de l'essence d'une chose et elle est dans le but de cette essence; ce n'est pas cette essence qui découle de cette genèse " (Gen an., 778 b 5-6) ?

Le même type de remarque vaut lorsque Rosen affirme : "Aristotle in effect collapses the distinction between the being of what is available for thinking and the being of thinking " (p. 76-77). L'auteur arrive à cette conclusion par le raisonnement suivant : "The eidos, or species-form, can be distinguished from the activity of noetic thinking as the content of a thought is distinguished from the thought. But this distinction is not ontological or, to use a quasi-Aristotelian word, it is not substantial. Of course there can be no thought without a content; to think is to think something. But the something that is thought is not thereby ontologically separate from the process of thinking*(p. 76). Est-il nécessaire de rappeler qu'Aristote conçoit l'intellection sur le modèle de la sensation où le sens est affecté. c'est-à-dire pâtit sous l'effet du sensible, et qu'elle ne se donne d'aucune manière à elle-même son objet, mais le reçoit bien plutôt du sensible en lequel il réside : "Venons-en à cette partie de l'āme par laquelle l'âme connait et pense [...]. Si donc l'intellection est analogue à la sensation, elle doit être ou une sorte de passion sous l'action de l'intelligible ou quelque autre chose de semblable. Le principe de l'intellection doit donc ètre [...] capable de recevoir la forme et tel en puissance que la forme [...] et se comporter à l'égard des intelligibles de la mème manière que la faculté sensitive à l'égard des sensibles "(De anima, 429 a 10-18) ? Dire que l'objet intelligible existe dans les formes sensibles (ibid., 432 a 4-5) et non pas séparé substantiellement des grandeurs sensibles ne signifie pas (pace Rosen) que cet objet n'existe pas, ni non plus, comme l'auteur le soutient ( $c f$. p. 77) qu'il cesserait d'exister si on cessait de le penser ! Ce reproche adressé à Aristote de ne pas penser l'intelligible comme ontologiquement ou substantiellement séparé se comprend dans la bouche d'un platonicien : il ne se comprend pas dans la bouche d'un platonicien qui soutient que Platon n'y souscrivait pas. À moins que ce à quoi Platon souscrivait et auquel Rosen reproche à Aristote de ne pas souscrire c'est, non pas la séparation de l'intelligible par rapport au sensible. mais la séparation de l'intelligible par rapport à l'intellection. Seulement c'est là, séparation de l'intelligible par rapport à l'intellection et non par rapport au sensible. l'essentiel de la thèse aristotelicienne.

Ce qu'on constate de manière générale dans l'ouvrage de Rosen c'est un parti pris anti-aristotélicien. Guand ce n'est pas Aristote lui-même qui est critiqué, ce sont les aristotélisants encouragés dans leurs interprétations par Aristote ( $c f$. p. 26-35). Or, de notre point de vue, il y a plus à tirer de l'Aristote platonicien contre Heidegger que de l'Aristote heideggérien contre Platon. En mésinterprétant Aristote et en accentuant son opposition à Platon, Rosen apporte au discours heideggérien une légitimité indue et se complique inutilement la tâche de le réfuter. D'un point de vue stratégique comme sur le fond, c'est, nous semble-t-il, une erreur. Par chance, c'est une erreur qui n'empèche pas l'auteur d'atteindre sa première cible, qui reste Heidegger.

Faculté de philosophie Université Laval 